\title{
Optimization of cycle time on signalized intersections of H.E.A Mokodompit Street - M.T Haryono - H.A. Nasution Kendari city based on traffic flow volume
}

\author{
Ridwan Syah Nuhun 1, Usman Rianse 2, Marsuki Iswandi 2, Adris Ade Putra ${ }^{2,}{ }^{*}$, Abdul Kadir 2, La Ode \\ Muhammad Golok Jaya ${ }^{2}$ and Sitti Nurjanah Ahmad ${ }^{2}$ \\ ${ }^{1}$ Management Science Study Program, Halu Oleo University, Kendari, Southeast Sulawesi, Indonesia. \\ 2 Lecturer of Halu Oleo University, Kendari, Southeast Sulawesi, Indonesia.
}

GSC Advanced Engineering and Technology, 2021, 01(01), 039-048

Publication history: Received on 27 March 2021; revised on 02 May 2021; accepted on 05 May 2021

Article DOI: https://doi.org/10.30574/gscaet.2021.1.1.0026

\begin{abstract}
Intersection of H.E.A. Mokodompit Street - M.T. Haryono - H.A. Nasution is one of the signalized intersections in Kendari City which has congestion problems, vehicle accumulation and vehicle queues at each arm of the intersection at rush hour due to the large volume of traffic flow and not optimal cycle timing from the traffic light signal. The purpose of this study is to optimize the cycle time of traffic control light signals based on traffic volume and to analyze the performance of these intersections.

The results of the analysis based on the volume of traffic flow obtained the optimal cycle time of 72 seconds with the division of green time in each approach by 18 seconds for the north approach, 14 seconds for the eastern approach and 28 seconds for the south approach.
\end{abstract}

The degree of saturation at each intersection arm is 0.82 which is at the service level D.

Keywords: Signalized Intersection; Optimal Cycle Time; Service Level

\section{Introduction}

An intersection is a location/area where two or more roads join or intersect/cross. The most common types of intersections in urban areas are unmarked intersections. This type is suitable to be applied to traffic flow on minor roads and relatively small turning movements, however, the traffic on the main road is very high so that accidents for motorists on minor roads are increasing, so it is necessary to have traffic lights [7]. Intersection planning with traffic light control must be planned properly and in accordance with traffic flow needs, because inappropriate planning will lead to new conflicts in intersections with the emergence of larger traffic delays, long queues and decreased intersection capacity as a result due to a malfunctioning of the intersection optimally [6]

Intersection on H.E.A Mokodompit Street - M.T. Haryono - H.A. Nasution is one of the intersections with signals in Kendari City and is better known as the New Campus intersection because it is located at the entrance to the New Campus of Halu Oleo University (UHO). This intersection is an intersection with type IT 322 which is in an area with a very large traffic pull because apart from being an educational area, in this area there are also other public facilities such as banking facilities and shopping places so that congestion is not uncommon at the intersection.

\footnotetext{
* Corresponding author: Adris Ade Putra

Halu Oleo University, Kendari, Southeast Sulawesi, Indonesia.
} 
The occurrence of congestion, accumulation of vehicles and queues of vehicles at each arm of the intersection at rush hours due to the large volume of traffic flow and the not optimal cycle time settings of the traffic control light signal are problems that exist at this intersection so that researchers are encouraged to review the timing optimal cycle based on the volume of traffic flow at the intersection.

The purpose of this study is to optimize the cycle time of traffic control light signals based on traffic volume and to analyze the performance of these intersections.

\section{Literature review}

An intersection is an area where two or more roads meet, join, intersect or cross. An intersection can also be referred to as a meeting between two or more roads, either one level or not a level or a point in the road network where roads meet and the road intersects each other [3]. An intersection is a traffic conflict place that is prone to accidents due to conflicts between vehicles and other vehicles or between vehicles and pedestrians. Therefore it is an important aspect of traffic control [2]

This type of intersection carries traffic flow from the foot of the intersection as is without any regulation, at this intersection a general priority rule is usually used, vehicles on the main road (major roads) always have a higher priority than all vehicles moving on the road [1]

In general, traffic signals are used for one or more reasons, namely to avoid intersection congestion due to high traffic flow, thus ensuring that a certain capacity can be maintained, even during peak hour traffic conditions[5]. The parameters used in the calculation of cycle times and analysis of intersection performance are signaled by the Indonesian Road Capacity Regulation method, namely Traffic Flow Volume (Q), Saturated Flow (S), Cycle Time and Green Time, Junction Capacity (C), Degree of Saturation (DJ) .

\subsection{Traffic Flow}

The amount of traffic volume is expressed in the following formula $Q=Q K r+(Q K b \times$ ekrKb$)+(Q S m \times e k r S m)$.

Traffic flow (Q) for each movement (turn left QBKI, go straight QLRS, turn right QBKA), converted from vehicles per hour (vehicle / hour) to light vehicles per hour (skr/hour) using the light vehicle equivalent (ekr) for each protected and protected approach as in the following Table 1.

Table 1 Light Vehicle Equivalence

\begin{tabular}{|l|l|l|}
\hline \multirow{2}{*}{ Transportation type } & \multicolumn{2}{|l|}{ Ekr For Approach Type } \\
\cline { 2 - 3 } & Protected & Challenged \\
\hline Light Vehicle (KR) & 1.0 & 1.0 \\
Heavy Vehicle (KB) & 1.3 & 1.3 \\
Motorcycle (SM) & 0.2 & 0.4 \\
\hline
\end{tabular}

\subsection{Saturated Flow}

Saturated flow is the amount of queue departures for vehicles at an approach during green time. The amount of saturated current is stated in the following equation:

$\mathrm{S}=$ So $\times \mathrm{F} 1 \times \mathrm{F} 2 \times \mathrm{F} 3 \mathrm{xF} 4 \mathrm{x} \ldots \ldots . \mathrm{x} \mathrm{Fn}$

For the shielded approach (type P) the basic saturation current is determined as So $=600 \mathrm{x}$ LM

The factors of adjustment are made for the following conditions:

- $\quad$ City size (UK) in million inhabitants.

- $\quad$ Side Barriers (HS).

- $\quad$ Slope (G) in\%, increase $(+)$ or decrease $(-)$. 
- $\quad$ Right Turn Movement (BKA) in\%.

- $\quad$ Movement Turn left (BKI) in\%.

- Vehicle Parking

Determining the value of the city size correction factor (FUK) is obtained using Table 2.

Table 2 City Size Adjustment Factors (FUK)

\begin{tabular}{|l|l|}
\hline $\begin{array}{l}\text { City dwellers } \\
\text { (Million Lives) }\end{array}$ & $\begin{array}{l}\text { Adjustment Factor } \\
\text { City Size (Fcs) }\end{array}$ \\
\hline$>3.0$ & 1.05 \\
\hline $1.0-3.0$ & 1.00 \\
\hline $0.5-1.0$ & 0.94 \\
\hline $0.1-0.5$ & 0.83 \\
\hline$<0.1$ & 0.82 \\
\hline
\end{tabular}

The side friction correction factor (FHs) is a function of the type of road environment, the level of side friction and the ratio of non-motorized vehicles. If the side disturbance is not known it can be assumed a high value so that there is no over estimate for capacity, it can be seen in Table 3.

Table 3 Side Barriers Adjustment Factors (FHs).

\begin{tabular}{|c|c|c|c|c|c|c|c|}
\hline \multirow{2}{*}{ Road Type } & \multirow{2}{*}{$\begin{array}{l}\text { Side } \\
\text { Barriers }\end{array}$} & \multirow{2}{*}{ Phase Type } & \multicolumn{5}{|c|}{ Non-Motorized Vehicle Ratio } \\
\hline & & & 0.00 & 0.05 & 0.1 & 0.15 & 0.2 \\
\hline \multirow{6}{*}{$\begin{array}{l}\text { Commercial } \\
\text { (Com) }\end{array}$} & \multirow{2}{*}{ High } & Challenged & 0.93 & 0.88 & 0.84 & 0.79 & 0.74 \\
\hline & & Protected & 0.93 & 0.91 & 0.88 & 0.87 & 0.85 \\
\hline & \multirow{2}{*}{ Moderate } & Challenged & 0.94 & 0.89 & 0.85 & 0.80 & 0.75 \\
\hline & & Protected & 0.94 & 0.92 & 0.89 & 0.88 & 0.86 \\
\hline & \multirow{2}{*}{ Low } & Challenged & 0.95 & 0.9 & 0.86 & 0.81 & 0.76 \\
\hline & & Protected & 0.95 & 0.93 & 0.90 & 0.89 & 0.87 \\
\hline \multirow{6}{*}{$\begin{array}{l}\text { Settlement } \\
\text { (Res) }\end{array}$} & \multirow{2}{*}{ High } & Challenged & 0.96 & 0.91 & 0.86 & 0.81 & 0.78 \\
\hline & & Protected & 0.96 & 0.94 & 0.92 & 0.89 & 0.86 \\
\hline & \multirow{2}{*}{ Moderate } & Challenged & 0.97 & 0.92 & 0.87 & 0.82 & 0.79 \\
\hline & & Protected & 0.97 & 0.95 & 0.93 & 0.90 & 0.87 \\
\hline & \multirow{2}{*}{ Low } & Challenged & 0.98 & 0.93 & 0.88 & 0.83 & 0.80 \\
\hline & & Protected & 0.98 & 0.96 & 0.94 & 0.91 & 0.88 \\
\hline \multirow{2}{*}{$\begin{array}{l}\text { Limited Access } \\
\text { (At) }\end{array}$} & \multirow{2}{*}{$\mathrm{T} / \mathrm{S} / \mathrm{R}$} & Challenged & 1.00 & 0.95 & 0.9 & 0.85 & 0.8 \\
\hline & & Protected & 1.00 & 0.98 & 0.95 & 0.93 & 0.9 \\
\hline
\end{tabular}

The gradient factor is a function of the slope of the intersection where according to the field conditions what percentage of the incline or descent of the road will be studied. To determine the gradient correction factor (FG), it can be seen in Figure 4.2 . 


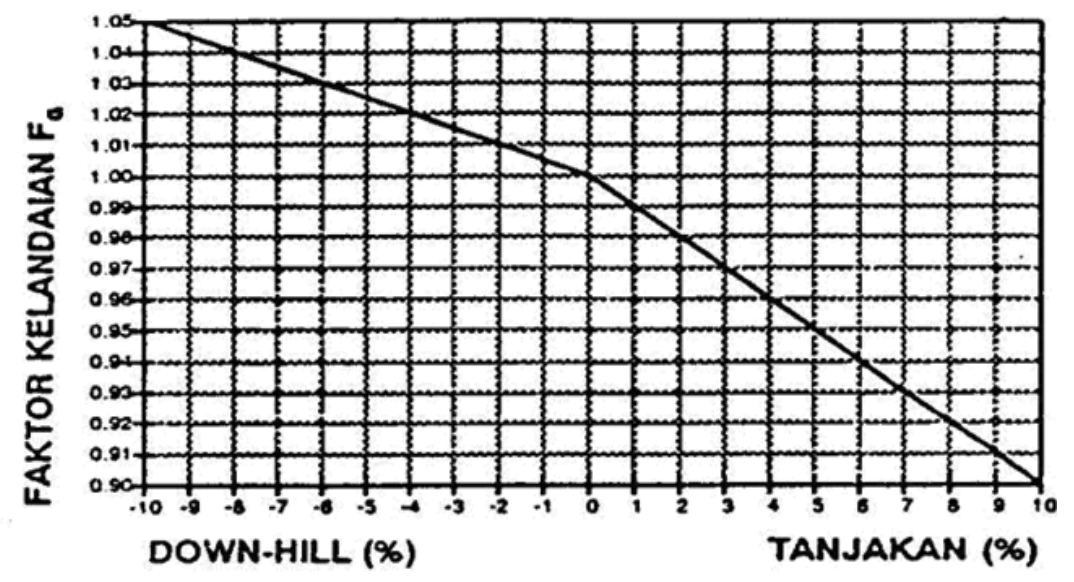

Figure 1 Gradient Correction Factor (Fg) (Source: PKJI, 2014)

The right turn correction factor (FBka), is a function of the ratio of vehicles turning right to the total volume of the vehicle, FBka can be determined using Figure 2 .

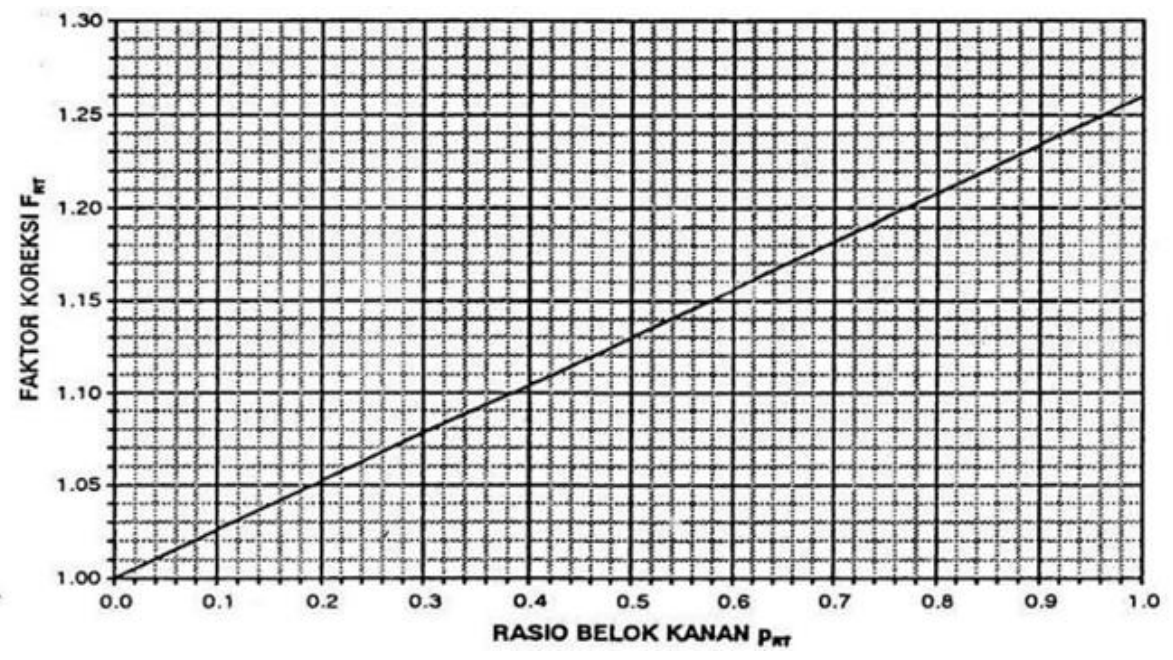

Figure 2 Correction Factors Turn Right (FBka) (Source: PKJI, 2014)

Left turn correction factor (FBki), is a function of the ratio of vehicles turning left to the total volume of vehicles, this factor is only for the approach type without turning left on the road (BkiJT). FBki can be determined using Figure 3.

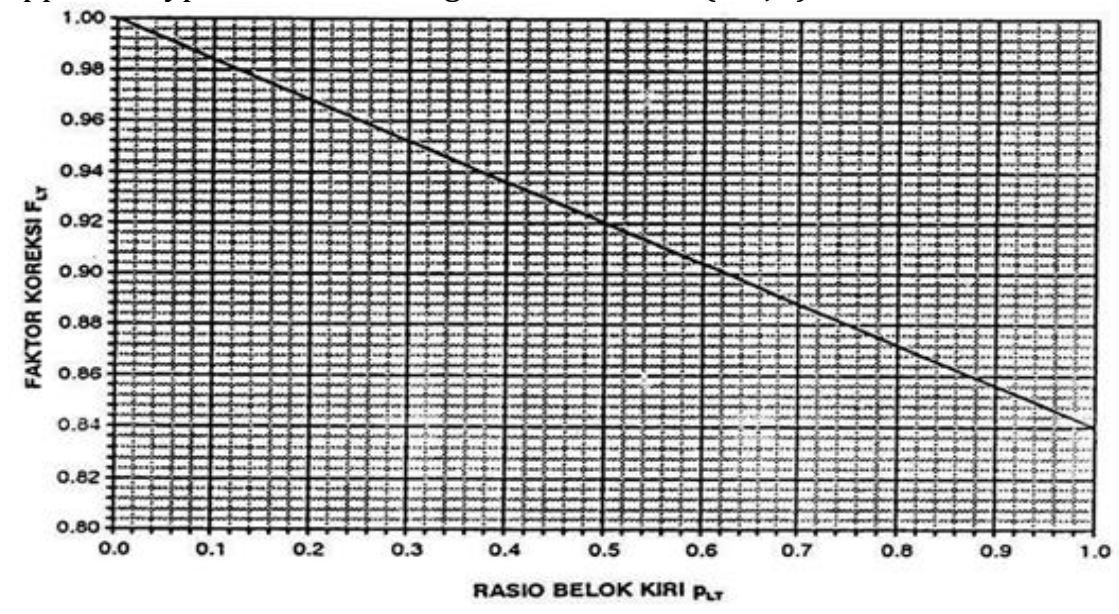

Figure 3 Correction Factors Turn Left (FBki) (Source: PKJI, 2014) 
The parking correction factor (Fp) is the distance from the stop line to the first parked vehicle and the approach width, the parking correction factor can be determined using Figure 4 below.

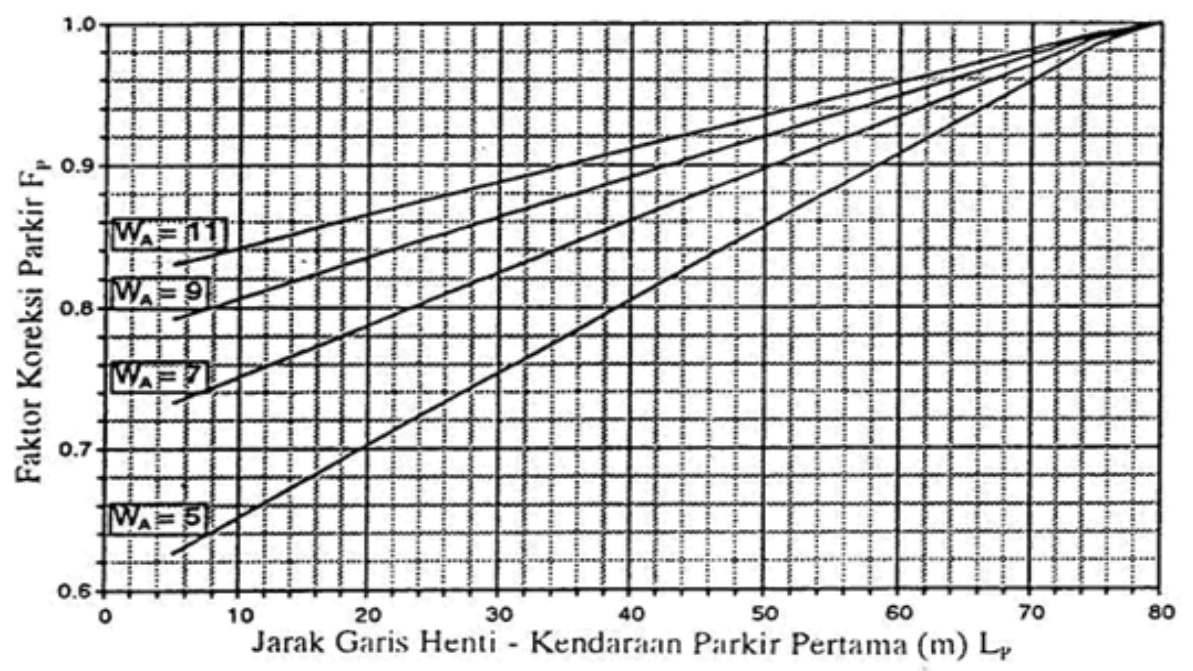

Figure 4 Parking Correction Factors (Fp) (Source: PKJI, 2014)

\subsection{Cycle Time And Green Time}

Cycle time is the time for a complete sequence of signal indications (between two consecutive green starts at the same phase). The cycle time value can be determined using the following equation:

$c=\left(1,5 \mathrm{H}_{\mathrm{H}}+5\right) /\left(1-\sum \mathrm{R}_{\mathrm{Q}} / \mathrm{S}\right.$ critical $)$

Table 4 Eligible Cycle Times.

\begin{tabular}{|l|l|}
\hline Setting Type & Eligible Cycle Time (sec) \\
\hline Two-phase arrangement & $40-80$ \\
Three phase arrangement & $50-100$ \\
Four phase arrangement & $80-130$ \\
\hline \multicolumn{2}{|c|}{ Source: PKJI 2014 } \\
\hline
\end{tabular}

For the purposes of designing the normal value of time between green (yellow time + all red time) can be used as in the following Table 5.

Table 5 Green Delivery Time.

\begin{tabular}{|l|l|l|}
\hline Intersection Size & Average Road Width (m) & Normal Value Between Green Time \\
\hline Small & $6-9$ & $4 \mathrm{sec} /$ phase \\
Moderate & $10-14$ & $5 \mathrm{sec} /$ phase \\
Big & $\geq 15$ & $\geq 6 \mathrm{sec} /$ phase \\
\hline
\end{tabular}

The Green Time Value can be determined using the following equation:

$$
\mathrm{Hi}=(\mathrm{c}-\mathrm{HH}) *\left(\mathrm{RQ} / \mathrm{S} \text { critical } / \sum \mathrm{i}(\mathrm{RQ} / \mathrm{S} \text { critical }) \mathrm{I}\right.
$$

\subsection{Junction Capacity}

Junction capacity is the maximum amount of traffic flow that can be maintained in each approach in one direction over a certain period of time. 
The capacity value is determined using the following equation $\mathrm{C}=\mathrm{S} \times \mathrm{H} / \mathrm{c}$

\subsection{Degree of Saturation}

The degree of saturation is the ratio of traffic flow to capacity at an intersection approach. The value of the degree of saturation is stated in the following equation $\mathrm{Dj}=\mathrm{Q} / \mathrm{C}$

\subsection{Level of Service}

Based on the Regulation of the Minister of Transportation Number 14 of 2005 concerning the Characteristics of the Level of Services (LOS) are as follows:

Table 6 Characteristics of Service Levels

\begin{tabular}{|l|l|l|}
\hline $\begin{array}{l}\text { Level Of Service } \\
\text { (LOS) }\end{array}$ & Characteristics & Scope Limit (Q / C) \\
\hline A & $\begin{array}{l}\text { Free flow conditions at high speed, the driver selects the } \\
\text { desired speed without resistance }\end{array}$ & $0.0-0.20$ \\
\hline B & $\begin{array}{l}\text { The flow is stable, but the operating speed is starting to be } \\
\text { limited by traffic conditions. The driver has that freedom } \\
\text { enough to choose the speed }\end{array}$ & $0.21-0.44$ \\
\hline C & $\begin{array}{l}\text { The current is stable, but the speed and motion of the vehicle } \\
\text { is controlled, the driver is limited in choosing the speed }\end{array}$ & $0.45-0.74$ \\
\hline D & $\begin{array}{l}\text { The current is nearing unstable, the speed is still controlled, } \\
\text { the Q / C is still tolerable }\end{array}$ & $0.75-0.84$ \\
\hline E & $\begin{array}{l}\text { Traffic volume is approaching / is at unstable flow capacity, } \\
\text { sometimes stopping }\end{array}$ & $0.85-1.00$ \\
\hline F & $\begin{array}{l}\text { Forced / jammed currents, low speed, V above capacity, long } \\
\text { queues and large obstacles occur }\end{array}$ & $>1.00$ \\
\hline
\end{tabular}

\section{Research methodology}

\subsection{Method of collecting data}

This type of research is a research with a survey method. Data collection in the form of primary data and secondary data.

Primary data is data obtained directly in the field in the form of geometric intersection data, traffic flow data and side friction data. Secondary data is in the form of data on the population of Kendari city.

\subsection{Survey Equipment and Materials}

The equipment and materials used in conducting direct field surveys are as follows:

- Counter tool to calculate the amount of traffic flow.

- Meter for measuring geometric paths.

- Stationery and other equipment.

- Survey form

- Computer / laptop for data processing. 


\section{Results and discussion}

\subsection{Geometric Data and Road Environment}

Table 7 Geometric Data and Road Environment

\begin{tabular}{|l|l|l|l|}
\hline Approach Code & Road Environment Type & Side Barriers & Entry Width (M) \\
\hline U & Com & R & 7 \\
\hline T & Com & R & 7 \\
\hline S & Com & R & 7 \\
\hline
\end{tabular}

\subsection{Traffic Flow Volume}

The traffic volume that is used in analyzing the intersection is the traffic volume at peak hours, where the peak volume occurs at 16.00 WITA - 17.00 WITA. The peak hour traffic volume can be seen in Table 8 .

Table 8 Peak Hour Traffic Flow Volume

\begin{tabular}{|c|c|c|c|c|c|c|c|c|c|}
\hline \multirow{3}{*}{ Time } & \multirow{3}{*}{ Approach } & \multicolumn{6}{|c|}{ Type of Vehicle / Hour } & \multirow{2}{*}{\multicolumn{2}{|c|}{ Total }} \\
\hline & & \multicolumn{2}{|l|}{$\mathrm{Kr}$} & \multicolumn{2}{|l|}{$\mathrm{Kb}$} & \multicolumn{2}{|l|}{$\mathrm{BC}$} & & \\
\hline & & Vehicle & $\begin{array}{l}\text { Junior } \\
\text { High }\end{array}$ & Vehicle & $\begin{array}{l}\text { Junior } \\
\text { High }\end{array}$ & Vehicle & $\begin{array}{l}\text { Junior } \\
\text { High }\end{array}$ & Vehicle & $\begin{array}{l}\text { Junior } \\
\text { High }\end{array}$ \\
\hline $16.00-17.00$ & $\mathrm{U}$ & 602 & 602 & 7 & 9 & 661 & 132 & 1270 & 743 \\
\hline $16.00-17.00$ & $\mathrm{~T}$ & 491 & 491 & 10 & 13 & 786 & 157 & 1287 & 661 \\
\hline $16.00-17.00$ & $\mathrm{~S}$ & 523 & 523 & 20 & 26 & 555 & 111 & 1098 & 660 \\
\hline
\end{tabular}

\subsection{Saturated Flow}

The saturation current value is obtained from the calculation of the basic saturation current with the following correction factors:

\subsubsection{Basic saturation current}

The intersection in question is an intersection with the type $\mathrm{P}$ approach, so that the basic saturation current is obtained using the equation So $=600 * \mathrm{Lm}$.

The basic saturation current for each approximation is as follows:

- $\quad$ The North Approach, So $=600 * 7=4200$

- The Eastern Approach, So $=600 * 7=4200$

- $\quad$ The Southern Approach, So $=600 * 7=4200$

\subsubsection{City size correction factor, $F_{U k}$}

Total population of Kendari City is included in the size of a small city, which ranges from 0.1 - 0.5 (data of BPS 2017). So that the city size correction factor used is $\mathrm{F}_{\mathrm{CS}}=0.83$

\subsubsection{Side drag correction factor, $F_{H s}$}

The intersection reviewed is an intersection located in a commercial area with a low side drag class, protected phase type, and a non-motorized vehicle ratio of 0.05 . used the value of $\mathrm{F}_{\mathrm{Hs}}=0.93$ 


\subsubsection{Slope correction factor, $F_{g}$}

The observed intersection has relatively flat geometric conditions, so the value of $F_{g}=1$ is used

\subsubsection{Parking correction factor, $F p$}

Parking correction value of each approach

- $\quad$ Approach North, $\mathrm{F}_{\mathrm{PU}}=0.71$

- $\quad$ The Eastern Approach, FPT $=0.71$

- The Southern Approach, FPS $=0.71$

\subsubsection{Correction factor turn right, $F_{B k a}$}

From Figure 2, the correct turn correction value for each approach is obtained as follows:

- $\quad$ Approach North, turn right ratio 0; $\mathrm{F}_{\mathrm{Bka}}=1$

- $\quad$ Eastern approach, turn right ratio $0.487 ; \mathrm{F}_{\mathrm{Bka}}=1.13$

- South approach, turn right ratio 0.452; $\mathrm{F}_{\mathrm{Bka}}=1.12$

\subsubsection{Left turn correction factor, $F_{B k i}$}

From Figure 3, it is obtained that the correction value for turning left of each approach is as follows:

- $\quad$ Approach North, turn left ratio 0; $F_{B k i}=1$

- $\quad$ Eastern approach, turn left ratio $0 ; \mathrm{F}_{\mathrm{Bki}}=1$

- South approach, turn left ratio $0 ; F_{B k i}=1$

From the calculation of the basic saturation current and the correction factors for each of the intersection approaches, the saturation current value $(\mathrm{S})$ is obtained as follows:

- The North Approach, $\mathrm{S}=2334$

- $\quad$ The Eastern Approach, $\mathrm{S}=2601$

- $\quad$ The Southern Approach, $\mathrm{S}=2578$

\subsubsection{Cycle Time And Green Time}

The time lost for every phase is 3 amber +1 all red $=4$ seconds, so the total time lost per cycle $\mathrm{H}_{\mathrm{H}}=12$ seconds, the total flow ratio is 0.681

$\mathrm{c}=\left(1.5 \mathrm{H}_{\mathrm{H}}+5\right) /\left(1-\sum \mathrm{R}_{\mathrm{Q} / \mathrm{s} \text { critical }}\right)$

$c=(1.5 * 12+5) /(1-0.681)$

$\mathrm{c}=72.2$ seconds

Green time for each approach, in table 9 below.

Table 9 Cycle times and green times

\begin{tabular}{|l|l|l|l|l|l|l|}
\hline Approach & $\mathbf{R Q} / \mathbf{S}$ & $\mathbf{H}_{\mathbf{H}}$ & $\boldsymbol{\Sigma} \mathbf{R}_{\mathbf{Q} / \text { s critical }}$ & $\mathbf{P R}$ & $\mathbf{c}$ & Green Time \\
\hline $\mathrm{U}$ & 0.199 & 12 & 0.681 & 0.292 & 72 & 18 \\
\hline $\mathrm{T}$ & 0.165 & 12 & 0.681 & 0.243 & 72 & 14 \\
\hline $\mathrm{S}$ & 0.317 & 12 & 0.681 & 0.466 & 72 & 28 \\
\hline \multicolumn{7}{|c|}{ Source: Analysis Results, 2021} \\
\hline
\end{tabular}

Based on the above analysis, the cycle time value is 72 seconds, by adjusting the amount of traffic flow at each intersection, the green time value is obtained as in table 9 . 


\subsection{Capacity and Degree of Saturation}

The capacity of the signalized intersection is determined from the amount of saturated current and the green ratio in each arm, as shown in Table 10 below.

Table 10 Capacity and Degree of Saturation.

\begin{tabular}{|l|l|l|l|l|l|l|}
\hline Approach & $\begin{array}{l}\text { Saturated } \\
\text { Flow }\end{array}$ & $\begin{array}{l}\text { Cycle Time } \\
\text { C (det) }\end{array}$ & $\begin{array}{l}\text { Green } \\
\text { Time } \\
\text { H (det) }\end{array}$ & $\begin{array}{l}\text { Capacity } \\
\text { C }\end{array}$ & $\begin{array}{l}\text { Current } \\
\text { (Q) } \\
\text { (skr / hour) }\end{array}$ & $\begin{array}{l}\text { Degree of } \\
\text { saturation } \\
\text { (D)) }\end{array}$ \\
\hline $\mathrm{U}$ & 2334 & 72 & 18 & 566 & 464 & 0.82 \\
\hline $\mathrm{T}$ & 2601 & 72 & 14 & 524 & 430 & 0.82 \\
\hline $\mathrm{S}$ & 2578 & 72 & 28 & 998 & 818 & 0.82 \\
\hline
\end{tabular}

\subsection{Service level}

Based on the results of the analysis in Table 10 , the degree of saturation in each of the intersection arms is 0.82 , thus the level of service at the intersection is included in the service level category D.

With a degree of saturation value of 0.82 , it shows that the distorted state is close to an unstable condition, so there is a need for efforts to increase the capacity of the intersection, either through geometric improvements or through other traffic engineering management to improve and improve the intersection performance.

\section{Conclusion}

From the results of the analysis based on the volume of traffic flow, can be drawn conclusions as follows:

- The optimal cycle time is 72 seconds with the division of green time in each approach of 18 seconds for the north approach, 14 seconds for the eastern approach and 28 seconds for the southern approach.

- The degree of saturation value is 0.82 , thus the intersection service level is included in the service level of D category, this indicates that the distorted condition can be said to be close to an unstable condition.

\section{Recommendations}

- The existence of traffic growth which is increasing every year due to the increasing number of vehicle ownership, it is necessary to study the optimization of cycle times on a regular basis in order to obtain a cycle time that is in accordance with the volume of traffic flow.

- To improve and improve intersection performance, it is necessary to increase intersection capacity, either through geometric improvements or through traffic engineering management.

\section{Compliance with ethical standards}

\section{Acknowledgments}

Thank you very much to Prof. Dr.Ir. Usman Rianse. MS, has helped us morally and materially so that we can complete this research. Hopefully this research will be useful for the development of science and technology

\section{Disclosure of conflict of interest}

There is no conflict of interest in this research.

\section{References}

[1] Abubakar, 1996, Towards Orderly Road Traffic and Transportation, enhanced edition, Jakarta, Director General of Land Transportation 
[2] Gita Puspa Artiani and Rizda Azhiary (2019) Efforts to Improve the Performance of the Four-Signal Intersection on Jalan Duren Tiga Selatan Using the 2014 Indonesian Road Capacity Guidelines (PKJI) Method: Journal of the University of Muhammadiyah Jakarta (2019)

[3] Morlok, Edward K. 1991. Introduction to Engineering and Transportation Planning. Erlangga: Jakarta

[4] Prasetyo EW. Optimization of the Performance of the Intersection (Case Study: Intersection Dr. Rajiman LAweyan, Surakarta). Civil Engineering Study Program, Faculty of Engineering, Muhammadiyah University of Surakarta. 2014.

[5] Public Works Department. Indonesian Road Capacity Regulation (PKJI), Directorate General of Highways. 2014.

[6] Sraun, Delsiana., Rumayar, ALE, Jefferson, Longdong., 2018. Analysis of Traffic Performance of the Three-Armed Crossing in Manado (Case Study: RE Martadinata Street Intersection), Journal of Civil Static Vol. 6 July 2018 (481490) ISSN: 2337-6732, Sam Ratulangi University Manado

[7] Wijayanto, Bambang. 2017. Traffic Monitoring Management at Road Intersections in Denpasar. Bali: STMIK STIKOM Bali. 